\title{
Efficacy of hamstring stretching programs in schoolchildren. A systematic review
}

\author{
Carlos-Alberto BECERRA FERNANDEZ1 ${ }^{\text {, Rafael MERINO-MARBAN2 }}$
}

\begin{abstract}
The main purpose of the present review was to examine the scientific literature on the effects of physical education-based stretching programs on hamstring extensibility in schoolchildren aged 6-11 years. For this purpose relevant studies were searched from ten electronic databases dated up through May 2015. Of the 25 potentially relevant articles identified and retrieved for more detailed evaluation, only eight studies were included in the present review because they met the inclusion criteria. The overall results showed that incorporating hamstring stretching as a part of physical education classes produces a significant improvement in the scores of the tests: straight leg raise and classic sit-and-reach, for the experimental groups, but not for control groups. Stretching programs can be included in Physical Education classes, specifically during the warmup and the cool down periods in order to improve hamstring extensibility. Although it seems that the stretching exercises in the warm-up period could be less effective in gaining flexibility in school children. Studies that use a stretching volume between 4 and 7 minutes per session and 2-4 training classes per week, obtain statistically significant improvements on the levels of hamstring flexibility in the experimental groups. However, after a five-week detraining period, children revert back to their initial flexibility levels. Therefore, it seems appropriate that physical education teachers should implement stretching programs to improve the students' flexibility during the Physical Education classes.
\end{abstract}

Key words: Hamstring stretching, primary students, stretching program, review.

\section{Rezumat}

Scopul principal al acesteirecenzii a fost de a examina literatura de specialitate cu privire la efectele programelor de stretching asupra extensibilității mușchilor ischiogambieri la elevii cu vârste cuprinse între 6-11 ani. În acest scop, au fost cercetate studii relevante din zece baze de date electronice datate până în mai 2015. Din cele 25 de articole potențial relevante identificate și extrase pentru o evaluare mai detaliată, doar opt studii au îndeplinit criteriile de includere înaceastă recenzie. Rezultatele globale au arătat că includerea exercițiilor de stretching pentru mușchii ischiogambieri în cadrul orelor de educație fizică determină o îmbunătățire semnificativă a testelorLasègue și sit-and-reach, pentru loturile experimentale, dar nu și pentru cele de control. Programele de stretching pot fi incluse în orele de educație fizică, în special în timpul perioadelor de încălzire și relaxare cu scopul de a îmbunătăți extensibilitatea mușchilor ischiogambieri. Totuși, se pare că exercițiile de stretching efectuate în perioada de încălzire sunt mai puțin eficace în creșterea flexibilității la copiii de școală. Studiile care utilizează 2-4 sesiuni de antrenament pe săptămână cu durata între 4 și 7 minute pe sesiune, au obținut îmbunătățiri semnificative statistic ale flexibilității mușchilor ischiogambieri din grupele experimentale. Cu toate acestea, după o perioadă de cinci săptămâni fărăantrenament, copiii revin la nivelul inițial de flexibilitate. Prin urmare, este oportun ca profesorii de educație fizică să implementeze programe de stretching pentru a îmbunătăți flexibilitatea elevilor în timpul orelor de educație fizică.

Cuvinte cheie: stretching al ischiogambierilor, elevi din clase primare, program de stretching, recenzie.

\footnotetext{
${ }^{1}$ Physical Education Teacher, Secondary School Sagrado Corazon, Malaga, Spain. e-mail: carlossbecerra@gmail.com

2 Professor, PhD, Universidad de Malaga, Facultad de Ciencias de la Educacion, Spain.
} 


\section{Introduction}

Flexibility is a basic physical capacity subject to a process of regression when it is not trained, descending more sharply after age 20 in men and women [1]. For this reason, it is essential applying programs that pursue flexibility development and maintenance during early age to avoid this descent [2-4].

Many investigations have revealed muscle shortening in school age, especially in the hamstrings [3,5-8] which is mainly caused for the adoption of bad postural habits and the increase in sedentary behaviour [9].

The decrease in hamstring muscle length has been associated with muscle damage [10], a decrease in the mobility of the pelvis [11], alterations in the lumbar-pelvic rhythm $[12,13]$, appearance of other diseases such as low back pain [14], spondylolysis [15], spondylolisthesis, Scheuermann disease, herniated discs even of the lumbosacral region [16]. Since the loss of hamstring flexibility has a negative impact on people's health, it has been necessary to tackle this issue in the educational field through the Physical Education (PE) class. Flexibility is one of the capabilities that is within the motor situation "a" and the assessment criteria 5 and 6 in Primary Education, according to the Spanish Royal Decree of 28 February 126/2014 [17].

According to Santonja et al. [5] (2004) the high prevalence of sagittal spinal misalignments make necessary to include flexibility and strengthening exercises for the extensors of the spine and hamstring stretches with a proper disposition of the vertebral column in PE classes. Coledam et al. [18] (2012), indicate that the stretching exercises do not interfere with the planning of other class content within flexibility programs, due to the brief nature of the intervention which duration is not longer than 8 minutes per session. Rodriguez et al. [8] (2008) add that the PE class must be an ideal setting for hamstring shortness prevention since it has the potential of optimizing environmental conditions and giving prolonged feedback that reaches a large percentage of the population.

Therefore and based on the background described, the aim of this systematic review was to determine the effect of intervention programs focused exclusively on stretching the hamstring's muscle for improving flexibility in primary schoolchildren apparently healthy.

\section{Methods}

\section{Search strategy}

The following 10 electronic databases were searched from their inception through May 2015: SportDiscus, Scopus, Assia, Cinahl, Cocrhane, IBSS, Proquest Dissertation and Theses, Proquest Education Journals, ERIC, Web of Science. The search terms used were based on four concepts. Concept one included terms for the flexibility (Flexibility, hamstring stretching, elasticity, extensibility, ROM, range of motion, flexibility program); concept two included terms for people (child, kid, elementary student, primary students, school-age student, schoolchildren); concept three included terms for training program (training, detraining program, intervention, exercise) and concept four included terms for test (straight leg raise, straight-leg raise, knee extension, popliteal angle, sit-and-reach, sit and reach, toe-touch, toe touch, stand-and-reach, stand and reach, finger to floor distance, fingertip floor distance, forward bend, angular test, lineal test, hip, hamstring).

The terms of the same concept were combined together with the Boolean operator "OR" and then the four concepts were combined using the Boolean operator "AND" [18]. The keywords that consisted of more than one word were enclosed in quotes. In addition, the reference lists of all included papers were manually searched.

\section{Selection criteria}

The selection criteria to identify studies that examined the hamstrings stretching programs on flexibility improvement in primary school children were: (a) studies with apparently healthy participants who did not present any injury, physical and/or mental disabilities; (b) studies in which the hamstring extensibility criterion measurements used before and after the program are widely accepted in the scientific literature (e.g., straight leg raise or knee extension tests, classic or modified sit-and-reach test); (c) studies in which participants were not more than 11 years; (d) studies which included control group; (e) programs were focused on hamstring stretching exercises. In addition to papers, master/ doctoral dissertations 
and conference proceedings were also accepted. No language or publication date restrictions were imposed.

\section{Coding studies}

For this review, data were collected from studies that reported relationships between hamstrings stretching programs and flexibility improvement with apparently healthy children in Primary Education. From each selected study the following data were coded: Reference, sample size $(n)$, experimental and control groups, sex of participants, age of participants, duration of program, stretching time, volume, intensity, frequency, stretching exercises, test protocol and results. Because identification of study features is usually explicitly stated in each of the primary articles, the use of more than one rather was deemed unnecessary.

\section{Results}

\section{Study description}

Figure 1 shows a flow chart of the study selection process. Of the 5.861 literature search results, 30 potentially relevant publications were identified and retrieved for a more detailed evaluation. Finally, 23 studies did not meet the inclusion criteria and only 10 studies were included in the present review.

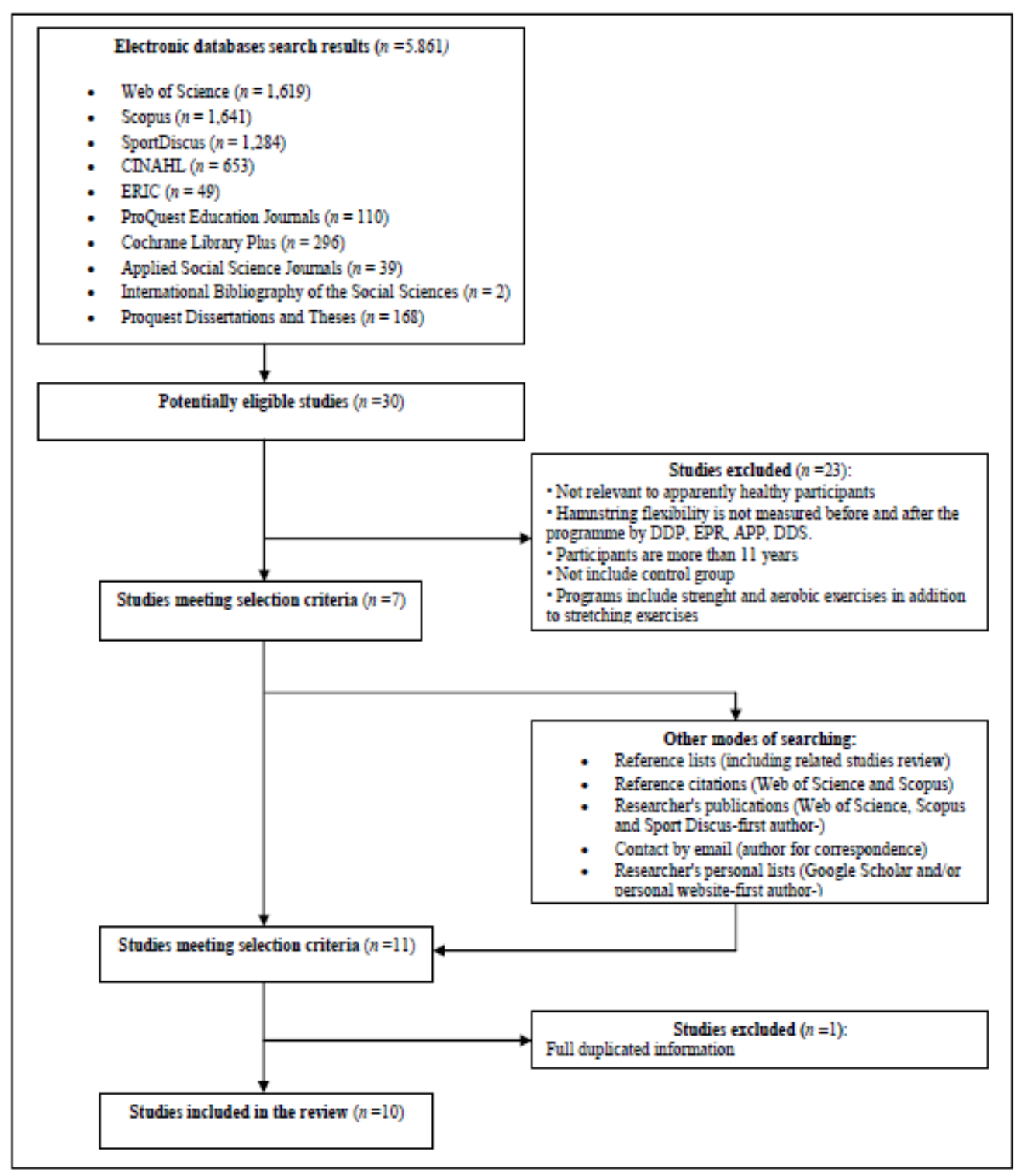

Figure 1. Flow chart of studies selection process 
The general characteristics of the studies which included hamstring stretching programs as a part of PE classes are shown in Table I.

Table I. General characteristics of the studies

\begin{tabular}{|c|c|c|c|c|c|c|}
\hline Author & Sample & $\begin{array}{c}\text { Duration } \\
\& \\
\text { frequency }\end{array}$ & $\begin{array}{l}\text { Stretching } \\
\text { technique }\end{array}$ & $\begin{array}{l}\text { Volume, exercises \& } \\
\text { total stretching time } \\
\text { per Week }\end{array}$ & Tests & Results \\
\hline $\begin{array}{l}\text { Coledam et al. } \\
(2012)\end{array}$ & $\begin{array}{l}\text { n: } 58 \\
\left(29+29{ }^{\lambda}\right) \\
\text { Age: } 8.53\end{array}$ & $\begin{array}{l}16 \mathrm{~W} \\
2 \mathrm{~s} / \mathrm{w}\end{array}$ & SA & $\begin{array}{l}1 \times 6 \text { SE in WU } \\
\text { 20s each SE } \\
\text { TST: } 120 \text { s. }\end{array}$ & CSR & 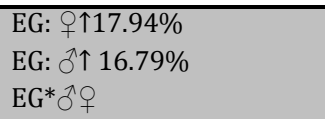 \\
\hline $\begin{array}{l}\text { Rodríguez et } \\
\text { al. (1999) }\end{array}$ & $\begin{array}{l}\mathrm{n}: 83 \\
\left(42 \text { 우 } 41 \bigcirc^{\Uparrow}\right) \\
\text { Age: } 10.28\end{array}$ & $2 \mathrm{~s} / \mathrm{w}$ & SP & $\begin{array}{l}5 ' \text { in } W U \text { \& } 2 ' \text { in } C D \\
\text { TST: } 420 \text { s. }\end{array}$ & $\begin{array}{l}\text { CSR } \\
\text { Feet to } 0 \\
\mathrm{~cm}\end{array}$ & $\begin{array}{l}\text { EG: } \downarrow 26 \% \text { to } 21.7 \% \text { FS } \\
\text { CG: } \uparrow 11.2 \% \text { to } 38.8 \% \text { FS. } \\
\text { EG* and CG } \downarrow\end{array}$ \\
\hline $\begin{array}{l}\text { Rodriguez et } \\
\text { al. (2008) }\end{array}$ & $\begin{array}{l}\text { n: } 90 \\
\left(49+, 410^{\lambda}\right) \\
\text { Age: } 10.3\end{array}$ & $\begin{array}{l}32 \mathrm{~W} \\
2 \mathrm{~s} / \mathrm{w}\end{array}$ & SA & $\begin{array}{l}3^{\prime} \text { in WU \& } 2^{\prime} \text { in CD } \\
\text { 20s each SE } \\
\text { TST: } 300 \text { s. }\end{array}$ & $\begin{array}{l}\text { CSR } \\
\text { Feet to } 0 \\
\mathrm{~cm}\end{array}$ & $\begin{array}{l}\text { Primary EG: } \uparrow 1.9 \mathrm{~cm} \text {, } \\
\text { CG: } \downarrow 3.8 \mathrm{~cm} \\
\mathrm{EG}^{*} \& \mathrm{CG} \downarrow\end{array}$ \\
\hline $\begin{array}{l}\text { Sainz de } \\
\text { Baranda et al. } \\
(2006)\end{array}$ & $\begin{array}{l}\text { n: } 62 \\
\left(32 \text {, } 30{ }^{\lambda}\right) \\
\text { Age: } 10-11\end{array}$ & $\begin{array}{l}31 \mathrm{~W} \\
2 \mathrm{~s} / \mathrm{w}\end{array}$ & S & $\begin{array}{l}3 ' \text { in WU \& 2' in CD } \\
\text { 20s each SE } \\
\text { TST: } 300 \text { s. }\end{array}$ & $\begin{array}{l}\text { TT } \\
\text { Feet to } \\
23 \mathrm{~cm}\end{array}$ & $\begin{array}{l}\mathrm{EG}: \uparrow 8 \mathrm{~cm}, \mathrm{CG}: \downarrow 2.9 \mathrm{~cm} \\
\mathrm{EG}^{*} \& \mathrm{CG} \downarrow\end{array}$ \\
\hline $\begin{array}{l}\text { Santonja et al. } \\
\text { (2007) }\end{array}$ & $\begin{array}{l}\text { n: } 62 \\
\text { Age: } 10-11\end{array}$ & $\begin{array}{l}31 \mathrm{~W} \\
\text { GE1: } 2 \mathrm{~s} / \mathrm{w} \\
\text { GE2: } 4 \mathrm{~s} / \mathrm{w}\end{array}$ & SP & $\begin{array}{l}3 \text { ' in WU \& 2' in CD } \\
\text { 20s each SE } \\
\text { TST GE1: } 300 \text { s \& GE2: } \\
\text { 600s. }\end{array}$ & PSLR & $\begin{array}{l}\text { EG1: } \uparrow 8^{\circ} 5^{\circ}, \mathrm{EG} 2: \uparrow 16.9^{\circ} \\
\mathrm{CG}: \downarrow 1.8^{\circ} \\
\mathrm{EG}^{*} \& \mathrm{CG} \downarrow\end{array}$ \\
\hline $\begin{array}{l}\text { Sánchez et al. } \\
\text { (2014) }\end{array}$ & $\begin{array}{l}\mathrm{n}: 44 \\
\left(24 \text { 우 } 20{ }^{\Uparrow}\right) \\
\text { Age: } 7.84\end{array}$ & $\begin{array}{l}9 \mathrm{~W} \\
2 \mathrm{~s} / \mathrm{w}\end{array}$ & SP & $\begin{array}{l}3 \times 3 \mathrm{SE} \\
\text { 20s each SE } \\
\text { TST: } 180 \mathrm{~s} .\end{array}$ & CSR & EG \& CG: $p<0.05^{*}$ \\
\hline $\begin{array}{l}\text { Mayorga-Vega } \\
\text { et al. (2014d) }\end{array}$ & $\begin{array}{l}\mathrm{n}: 45 \\
(19+, 26 \overbrace{}^{\Uparrow}) \\
\text { Age: } 10.9\end{array}$ & $\begin{array}{l}8 \mathrm{~W} \\
5 \mathrm{WD} \\
2 \mathrm{~s} / \mathrm{w}\end{array}$ & SP & $\begin{array}{l}3 \times 5 \text { SE } \\
\text { 20s each SE } \\
\text { TST: } 300 \text { s. }\end{array}$ & CSR & $\begin{array}{l}\text { EG pre-pos: } p<0.001^{*} \\
\text { EG: pre-retest: } p<0.01^{*} \\
\text { CG pre-re-test: } p=.006\end{array}$ \\
\hline $\begin{array}{l}\text { Mayorga-Vega } \\
\text { et al. }(2014 b)\end{array}$ & $\begin{array}{l}\mathrm{n}: 73 \\
\left(37+36{ }^{\lambda}\right) \\
\text { Age: } 9.0\end{array}$ & $\begin{array}{l}10 \mathrm{~W} \\
2 \mathrm{~s} / \mathrm{w}\end{array}$ & SP & $\begin{array}{l}3 \times 3 \mathrm{SE} \\
\text { 20s each SE } \\
\text { TST: } 180 \text { s. }\end{array}$ & CSR & $\begin{array}{l}\text { EG1 (WU) \& CG: } p<0.01^{*} \\
\text { EG2 (CD) and CG: } p<0.05^{*} \\
\text { WU \& CD: } p>0.05\end{array}$ \\
\hline $\begin{array}{l}\text { Mayorga-Vega } \\
\text { et al. (2014c) }\end{array}$ & $\begin{array}{l}\text { n: } 45 \\
\left(21+24{ }^{\Uparrow}\right) \\
\text { Age: } 9.89\end{array}$ & $\begin{array}{l}8 \mathrm{~W} \\
5 \mathrm{WD} \\
2 \mathrm{~s} / \mathrm{w}\end{array}$ & SP & $\begin{array}{l}3 \times 4 \text { SE } \\
\text { 20s each SE } \\
\text { TST: } 300 \text { s. }\end{array}$ & CSR & $\begin{array}{l}\text { EG \& CG pre-post: } \\
\text { p }<0.001^{*} \\
\text { EG \& CG pre-post- } \\
\text { intervention-post- } \\
\text { detraining: } p>0.05\end{array}$ \\
\hline $\begin{array}{l}\text { Merino- } \\
\text { Marban et al. } \\
(2015)\end{array}$ & $\begin{array}{l}\mathrm{n}: 45 \\
\left(19+, 26{ }^{\Uparrow}\right) \\
\text { Age: } 5.91\end{array}$ & $\begin{array}{l}8 \mathrm{~W} \\
5 \mathrm{WD} \\
2 \mathrm{~s} / \mathrm{w}\end{array}$ & SP & $\begin{array}{l}1 \times 3 \text { SE in CD } \\
20 \text { s each SE } \\
\text { TST: } 60 \text { s. }\end{array}$ & CSR & $\begin{array}{l}\text { EG pre-pos: } p<0.001^{*} \\
\text { EG pre-re-test: } p>0.05\end{array}$ \\
\hline \multicolumn{7}{|c|}{$\begin{array}{l}\text { Legend: CD: Cool Down, CG: Control Group, CSR: Classic Sit-and-Reach, EG: Experimental Group, FS: Frequency of Shortening, PSLR: } \\
\text { Passive Straight Leg Raise, s: seconds, SA: Static Active, SE: Stretching Exercise, SP: Static Passive, S/W: Session per Week, TST: Total } \\
\text { Stretching Time per Session, TT: Toe-Touch test, WU: Warm-up, W: weeks, WD: weeks of Detraining, } \uparrow: \text { Increase, } \downarrow: \text { Descent, }{ }^{2}: \text { boy, }+ \text { : } \\
\text { girl, *: Significant. }\end{array}$} \\
\hline
\end{tabular}

\section{Discussion}

The results of the present review indicated that incorporating hamstring stretching as a part of PE classes produces a significant improvement in the scores of the tests: Toe-Touch (TT), back-saver sitand-reach (BS SR), straight leg raise (SLR) and classic sit-and-reach (CSR), for the experimental groups, but not for control groups.

\section{Test}

The results showed that most of the studies used lineal tests such as the TT and the CSR for assess the hamstring flexibility. Only Santonja et al. [20] (2007) included in his research the angular test that specifically measure hip flexion with the knee extended (SLR) to assess hamstring extensibility. 
Due to the necessity of sophisticated instruments, qualified technicians, and time constraints, the use of these angular tests seem to be limited in several studies $[4,8,18,21]$. That is why the CSR is the most frequently used flexibility test in school setting because its procedure is simple, easy to administer, and require minimal skills training $[22,23]$.

According to Mayorga-Vega, Merino-Marban and Viciana [24] (2014a) all SR tests have a moderate mean criterion-related validity for estimating hamstring extensibility ( $r \mathrm{p}=0.46-0.67)$.

Consequently, when the use of angular tests is limited such as in a school setting or in large scale studies, scientists and practitioners could use the SR tests as a useful alternative for hamstring extensibility estimation, but not for estimating lumbar extensibility.

\section{Stretch in different phases of the PE class}

Most of studies revealed that stretching programs can be included in PE classes, specifically during the warm-up (WU) and the cool down (CD) period in order to improve hamstring extensibility $[4,8,18,20,21,25,26]$.

It appears that the time at which the stretching is performed may influence the improvement in flexibility [27]. This study found that the warm-up group (WUG) and cool-down group (CDG) did not show statistically significant post and preintervention differences on hamstring extensibility. Nevertheless, CDG students obtained a slightly higher magnitude effect when compared with the WUG $(g=0.19)$. This result could indicate that performing stretching exercises in the $\mathrm{CD}$ period might relax the muscles worked during the session, returning them to their previous length and even improving it. However, when stretching exercises are performed during the WU this could not happen. Therefore, the stretching exercises in the WU period could be less effective in gaining flexibility in school children. Retaining flexibility before the main part of the session could decrease during PE class by shortening of the muscle that might be caused by the muscular contractions performing in motor activities.

Additionally, previous studies have shown that the inclusion of static stretching exercises during the WU negatively affects the posterior performance in important parameters such as explosive strength $[28,29,30]$, speed [31] or sports skills [32].

\section{Duration of the program and frequency}

Most of studies carry out programs between 8 and 32 weeks and achieve flexibility improvements on hamstring muscle in schoolchildren. These positive results can even be found in adolescents who participated in programs which had a lesser duration: 6 weeks $[33,34]$.

All articles of this review usually determine 2 training sessions per week. However, the flexibility improvements are greater when the number of sessions per week is higher. Santonja et al. [20] (2007) compared two programs with two and four classes per week. The results showed that an increase in the number of weekly PE classes produces more improvement of flexibility in children. This author increased the weekly program using the extracurricular classes as well as PE classes. Consequently, both intervention programs conducted during PE classes and extracurricular programs are effective in improving the flexibility of schoolchildren.

Nevertheless, in a recent study of Mayorga-Vega et al. [40] (2015) was found that both a stretching program performed once a week and a program performed two session per week improved hamstring extensibility in schoolchildren. No statistically significant differences between the two experimental groups were found $(p>0.05)$. Although high school students (12-14 years) participated in this study, its results provide an important fact with regard to the frequency of stretching. In addition, including this type of program would be more feasible for PE teachers because there are many curricular contents to be taught and the subject is too restricted by its limited curriculum time allocation.

\section{Volume and intensity}

Regarding the total stretching volume, the authors show in their results that flexibility programs produce a significant improvement in the hamstring extensibility of experimental groups when muscles are stretched between 1 and 7 minutes per session. In relation with the duration of each exercise, the experimental groups of all studies achieved improvements in hamstring flexibility when was 
stretched for 20 seconds on each exercise. Therefore, it would be more interesting increase the number of repetitions initially and then, the time stretching, since most of the investigations show that is more effective increase the number of repetitions or flexibility exercises than increase the duration of them $[18,4,20,8]$.

With respect to the intensity, many studies used static stretching exercises where the position is reached progressively and safely in order to avoid injury on muscle $[20,4]$. If we observe the table I, all schoolchildren carried out stretching exercises maintained for 20 seconds, just to the point of mild discomfort and stopping before the stretch becomes painful. Therefore, the studies suggest that static stretches performed under low and medium intensity might be effective in improving hamstring extensibility.

\section{Re-test programs}

Until recently, most studies have only focused on the benefits and gains existing in hamstring flexibility after application of stretching programs. However, some authors have gone further and have wondered how long they can retain these gains after a program of several weeks $[26,35,36]$.

Current scientific information about the flexibility detraining is really scarce and contradictory $[37,38,39]$, especially among school age children $[35,36,26]$. Previous studies that carried out a PEbased stretching program observed statistically significant lost of hamstring extensibility after five weeks of detraining $[35,36,26]$. Although MayorgaVega et al. [36] (2014d) observed that schoolchildren retained significant gains, most of previous studies also found that children' flexibility levels decreased to baseline $[35,26]$.

Therefore, as after five weeks of flexibility detraining the effect of the stretching program has completely vanished, PE teachers should continue training students' flexibility after a shorter detraining period in order to maintain the gains obtained in the previous semesters. In this sense, the increase of active time for learning in extracurricular periods would represent an excellent strategy for PE teachers to pursue important objectives such as the flexibility improvement [26]. Hence, this strategy would avoid to loss the flexibility improvements previously obtained.
However, as Merino-Marban et al. [26] (2015) indicated, this strategy mainly depends on the students' autonomy. Therefore, apart from training their students how properly to perform the stretching exercises, PE teachers should take the appropriate didactic measures in order to ensure that their students really follow the exercises indicated.

\section{Stretching technique}

All programs in the present review include passive and active static stretching techniques to improve flexibility in children how it can see on table I. It seems that static passive techniques are mainly recommended in schoolchildren, since contribute to greater control of the spine aligned arrangement, rejecting the practice of ballistic techniques because of the limited control they have in their performance and the risk of muscle injury [26].

Therefore, future research might be interesting to apply programs using dynamic methods as active rebounds in schoolchildren.

\section{Conclusions}

Schoolchildren that held the stretch during 20 seconds in each exercise, use a total volume between 1 and 7 minutes per session and a frequency of 2-4 training classes per week, obtain statistically significant improvements on the levels of hamstring flexibility. However, after a five-week detraining period, children revert back to their initial flexibility levels.

Stretching programs can be included in PE classes, specifically during the WU and the CD period in order to improve hamstring extensibility. Although it seems that the stretching exercises in the WU period could be less effective than stretching in the $\mathrm{CD}$ in gaining flexibility in schoolchildren.

It seems that static passive and active techniques are mainly recommended in schoolchildren since contribute to greater control of the spine aligned arrangement.

The CSR is the most frequently used flexibility test in school setting because its procedure is simple, easy to administer, and require minimal skills training.

Moreover, stretching exercises would not interfere with the planning or execution of other class content due to the brief nature of the intervention 
which duration is not longer than 7 minutes per session.

\section{References}

1. Chodzko-Zajko W.J., Proctor D.N., Fiatarone Singh M.A., Minson C.T., Nigg C. R., Salem G.J., Skinner J.S. (ACSM) (2009). Exercise and Physical Activity for Older Adults, Medicine \& Science in Sports \& Exercise, 41(7):1510-1530.

2. Borras X., Comella A., Marín F., Comella R.R., Cirera, E. (2007) Aplicabilidad de la goniometría mediante videografía en el seguimiento de programas de flexibilidad, Biomecánica, 15(1):2833.

3. Kanásová J. (2008). Reducing shortened muscles in 10-12-yearold boys through a physical exercise program, Medicina Sportiva, 12:115-123.

4. Sainz de Baranda P., Rodríguez P.L., Santonja F.M., LópezMiñarro P.A., Andujar P., Ferrer V., Pastor A. (2006). Effects of hamstring stretching exercises on the toe-touch test in elementary schoolchildren, Journal of Human Movement Studies, 51(4):277289.

5. Santonja F., Rodríguez P.L., Sainz de Baranda P., López Miñarro P.A. (2004). Papel del profesor de educación física ante las desalineaciones de la columna vertebral, Selección, 13(1):5-17.

6. Brodersen A., Pedersen B., Reimers J. (1994). Incidence of complaints about heel, knee and back related discomfort among Danish children, possible relation to short muscles, Ugeskrift fot Laeger, 156:2243-2245.

7. Harreby M., Neergaard K., Jessen T., Larsen E., Storr-Paulsen A., Lindahl A., Fisker I., Laegaard E. (1999). Risk factors for low back pain in a cohort of 1389 Danish school children an epidemiologic study, European Spine Journal, 8:444-450.

8. Rodríguez P.L., Santonja F.M., López-Miñarro P.A., Sáinz de Baranda J.L., Yuste J. L. (2008). Effect of physical education stretching program on sit-and-reach score in schoolchildren, Science \& Sports, 23(3-4):170-175.

9. Penha P.J., Amado Joäo S.M. (2008). Muscle flexibility assessment among boys and girls aged 7 and 8 years old, Fisioterapia e Pesquisa, 15(4):387-391.

10. Cabry J., Shiple B., J. (2000). Increasing hamstring flexibility decreases hamstring injuries in high school athletes, Clinical Journal of Sport Medicine, 10:311-312.

11. Kendall F.P., McCreary E.K., Provance P.G., Rodgers M.M. Romani W.A. (2005). Muscles: Testing and function with posture and pain, 5th edition, Lippincott, Williams, \& Wilkins, Baltimore. 12. Esola M.A., McClure P.W., Fitzgerald G.K. Siegler S. (1996). Analysis of lumbar spine and hip motion during forward bending in subjects with and without a history of low back pain, Spine, 21:7178.

13. López-Miñarro P.A., Muyor J.M., Alacid F. (2012). Influence of hamstring extensibility on sagittal spinal curvatures and pelvic tilt in high-trained young kayakers, European Journal of Sport Science, 12(6):469-474.

14. Feldman D.E., Shrier I., Rossignol M., Abenhaim L. (2001). Risk factors for the development of low back pain in adolescence, American Journal of Epidemiology, 154(1):30-36.

15. Standaert C.J., Herring S. A. (2000). Spondylolysis: A critical review, British Journal of Sports Medicine, 34:415-422.

16. Kayser R., Mahlfeld K., Heyde C.E., Grasshoff H., Mellerowicz, H. (2006). Tight hamstring syndrome and extra or intraspinal diseases in childhood: a multicenter study, European Spine Journal, 15(4):403-408.

17. Royal Decree 126/2014, the 28th February, laying down the Curriculum for Primary Education, Government Gazette, 52, 19349-19420.

18. Coledam D.H.C., Arruda G.A., Ramos de Oliveira A. (2012). Chronic effect of static stretching performed during warm-up on flexibility in children, Revista Brasileira de Cineantropometria e Desempenho Humano, 14:296-304.

19. Benito Peinado P.J., Díaz Molina V., Calderón Montero F.J., Peinado Lozano A.B., Martín Caro C., Álvarez Sánchez M., Pérez Tejero J. (2007). Literature review in exercise physiology: Practical recommendations, Revista Internacional de Ciencias del Deporte, 6:1-11.

20. Santonja F., Sainz de Baranda P., Rodríguez P. L., López P.A. Canteras M. (2007). Effects of frequency of static stretching on straight leg raise in elementary school children, Journal of Sports Medicine and Physical Fitness, 47(3):304-308.

21. Rodríguez García P.L., Santonja Medina F., Canteras Jornada M., Delgado Fernández M., Fernández Piñera J., Balsalobre Marín J. (1999). Mejora de la extensibilidad isquiosural tras un programa escolar de estiramientos, Selección, 8(4):157-164.

22. Castro-Piñero J., Chillón P., Ortega F.B., Montesinos J.L., Sjöström M. Ruiz, J.R. (2009). Criterion-related validity of sit-andreach and modified sit-and-reach test for estimating hamstring flexibility in children and adolescents aged 6-17 years, International Journal of Sports Medicine, 30:658-662.

23. López Miñarro P.A., Sainz de Baranda P., Yuste Lucas J.L., Rodríguez García P.L. (2008). Validity of the unilateral sit-andreach test as measure of hamstring muscle extensibility. Comparison with other protocols, Cultura, Ciencia y Deporte, 3:8792.

24. Mayorga-Vega D., Merino-Marban R., Viciana J. (2014a). Criterion-related validity of sit-and-reach tests for estimating hamstring and lumbar extensibility: A meta-analysis, Journal of Sports Science and Medicine, 13(1):1-14.

25. Sánchez Rivas E., Mayorga-Vega D., Fernández-Rodríguez E., Merino-Marbán R. (2014). Effect of a hamstring stretching program during physical education lessons in primary education, Journal of Sport and Health Research, 6(2):159-168.

26. Merino-Marban R., Mayorga-Vega D., Fernandez-Rodriguez E., Vera Estrada F., Viciana J. (2015). Effect of a physical educationbased stretching programme on sit-and-reach score and its posterior reduction in elementary schoolchildren, European Physical Education Review 21(1):83-92.

27. Mayorga-Vega D., Merino-Marban R., Garrido F. J., Viciana J. (2014b). Comparison between warm-up and cool-down stretching programs on hamstring extensibility gains in primary schoolchildren, Physical Activity Review, 2:16-24.

28. Faigenbaum A.D., Belluci M., Bernieri A., Bakker B., Hoorens K. (2005). Acute effects of different warm-up protocols on fitness performance in children, Journal of Strength and Conditioning Research, 19:376-381.

29. Gelen E. (2011). Acute effects of different warm-up methods on jump performance in children, Biology of Sport, 28:133-138.

30. Duncan M.J., Woodfield L.A. (2006). Acute effects of warm up protocol on flexibility and vertical jump in children, Journal of Exercise Physiology online, 9:9-16.

31. Needham R.A., Morse C.I., Degens H. (2009). The acute effect of different warm-up protocols on anaerobic performance in elite youth soccer players, Journal of Strength and Conditioning Research, 23:2614-2620. 
Timişoara Physical Education and Rehabilitation Journal

32. Di Cagno A., Baldari C., Battaglia C., Gallotta M.C., Videira M., Piazza M., Guidetti L. (2010). Pre-exercise static stretching effect on leaping performance in elite rhythmic gymnasts, Journal of Strength and Conditioning Research, 24:1995-2000.

33. Reid D.A. McNair P. J. (2004). Passive force, angle and stiffness changes after stretching of hamstring muscles, Medicine and Science in Sports and exercise, 36:1944-1948.

34. Nelson R.T. Bandy W.D. (2004). Eccentric training and static stretching improve hamstring flexibility of high school males., Journal of Athletic Training, 39:254-258.

35. Mayorga-Vega D., Merino-Marban R., Sánchez-Rivas E., Viciana J. (2014c). Effect of a short-term static stretching training program followed by five weeks of detraining on hamstring extensibility in children aged 9-10 years, Journal of Physical Education and Sport, 14(3):355-359.

36. Mayorga-Vega D., Merino-Marban R., Vera-Estrada F., Viciana J. (2014d). Effect of a short-term physical education-based flexibility program on hamstring and lumbar extensibility and its posterior reduction in primary schoolchildren, Kinesiology, 46(2):227-233.

37. Cipriani D.J., Terry M.E., Haines M.A., Tabibnia A.P., Lysanova 0.(2012). Effect of stretch frequency and sex on the rate of gain and rate of loss in muscle flexibility during a hamstring-stretching program: A randomized single-blind longitudinal study, Journal of Strength and Conditioning Research, 26(8):2119-2129.
38. Rancour J., Holmes CF., Cipriani DJ. (2009). The effects of intermittent stretching following a 4-week static stretching protocol: A randomized trial, Journal of Strength and Conditioning Research, 23(8):2217-2222.

39. Willy R.W., Kyle B.A., Moore S.A., Chleboun G.S. (2001). Effect of cessation and resumption of static hamstring muscle stretching on joint range of motion, Journal of Orthopaedic and Sports Physical Therapy, 31(3):138-144.

40. Mayorga-Vega D., Merino-Marban R., Real J., Viciana J. (2015). A physical education-based stretching program performed once $a$ week also improves hamstring extensibility in schoolchildren: a cluster-randomized controlled trial, Nutricion Hospitalaria, 32(4):1715-1721. 